\title{
Assessment of Microbial Biomass Carbon and Microbial Biomass Nitrogen of Incubated Organic and Conventional Treated Soil in West Bengal, India
}

\author{
Soumyabrata Chakraborty* and Niharendu Saha \\ ${ }^{1}$ Department of Agriculture Chemistry and Soil Science, Bidhan Chandra Krishi \\ Viswavidyalaya, Nadia, West Bengal, India, Pin-741252 \\ *Corresponding author
}

A B S T R A C T

Ke y w o r d s
Microbial Biomass
Carbon, Microbial
Biomass Nitrogen,
Chloroform
extraction
fumigation method,
Conventional
method,
Organic method
Article Info
Accepted:
10 April 2020
Available Online:
10 May 2020

The experiment was conducted to assess Microbial biomass carbon and Nitrogen on 84 days organic and conventional incubated soils in Nadia district of West Bengal. Soil microbial biomass carbon \& nitrogen is determined by Chloroform Fumigation Extraction method (FE) followed by Kjeldal Digestion method. The results depicted that, microbial biomass carbon and nitrogen was more in organic soil of Phulia and Gayeshpur district rather than conventional method. The organic plot treated with $1 / 3^{\text {rd }}$ recommended dose of $\mathrm{N}$ from FYM, Vermicompost \& Neem Cake showed more level of MBC and MBN content among the other 2 treatment followed in Phulia and the organic plot treated with Sesbania Green Manure+ Vermicompost + Mustard Oil cake showed more level of MBC and MBN content among the other 1 treatment followed in Gayeshpur. Both the microbial biomass $\mathrm{C}$ and $\mathrm{N}$ showed a significance difference $(\mathrm{P}$ $\leqslant 0.05)$ in the different months of the season.
Soil is a complex system, in which, plant, macro, meso and microorganisms dispute water and nutrient sources for survival and whose physical, chemical and biological properties shows high special temporal changes. The microbial biomass is the main living component of soil organic matter and has been suggested as indicator of soil quality. Microbes constitute about one fourth of all living biomass on earth and are responsible for significant nutrient transformations involving both macro and micro nutrients (Alexander 1977). The microbial biomass consists mostly of bacteria and fungi, which decompose crop residues and organic matter in soil. This process releases nutrients, such as nitrogen $(\mathrm{N})$, into the soil that are available for plant uptake. 
About half the microbial biomass is located in the surface $10 \mathrm{~cm}$ of soil and most of the nutrient release also occurs here. Generally, up to $5 \%$ of the total organic $\mathrm{C}$ and organic $\mathrm{N}$ in soil exist in the microbial biomass component of soil organic matter.

When microorganisms die, these nutrients are released in forms that can be taken up by plants. The microbial biomass can be a significant source of $\mathrm{N}$. The amount of labile organic $\mathrm{C}$ is of particular importance as this provides a readily available carbon energy source for microbial decomposition. Soils with more labile $\mathrm{C}$ tend to have a higher microbial biomass. In our present study we concentrate the effect of microbial biomass content in organic soil and inorganic soil as microbial biomass content is more in organic soil due to retention of more amount of organic carbon in organic soil.

The different 5 (five) treated soil samples were collected from different Organic and conventional plots at Phulia and Gayeshpur (Nadia district) which is situated at $23.23^{\circ} \mathrm{N}$ latitude and $88.49^{\circ} \mathrm{E}$ longitude at an elevation of $10.25 \mathrm{~m}$ above mean sea level. In order to reduce heterogeneity of the field, composite soil sample samples were taken in a crisscross way from the surface soil $(0-15 \mathrm{~cm}$ depth). Soil samples were collected from Phulia in Nadia district having 3 different treatments.

Organic plots under Phulia include Strawberry and Rice intercropped with Bhindi and Chilli. Conventional plot under Phulia includes Rice. Following conventional cultivation soil samples were also collected from organic and inorganic plots of Rice from Central Research Farm, B.C.K.V. Gayeshpur, Nadia. A portion of live soil was preserved in freeze for microbial and biochemical studies such as microbial biomass carbon and nitrogen. The soil is then incubated for 84 days and then microbial biomass content of carbon can be determined by chloroform fumigation extraction method (Joergenson, 1995) followed by dichromate oxidation. Microbial Biomass nitrogen was determined by Kjeldal digestion method after obtaining the extract. Data of different forms of nitrogen is statistically analyzed for analyses of variance as well as critical difference were calculated at 5\% level to test the significance (SPSS version 18.0; SPSS, Inc., Chicago, IL, USA).

Data generated on microbial biomass carbon (MBC), nitrogen $(\mathrm{MBN})$ are presented in Table 1, 2. Generally, the results show positive influence of organic production systems with high $\mathrm{C}$ content, on soil microbial biomass over conventional farming systems with relatively lower organic carbon content. This is due to the positive relationship of microbial biomass growth and function to substrate $\mathrm{C}$ input into systems and amending the soil with compost which in turn induces an increase in soil microbial biomass (Araujo and Melo, 2011). Among the organic farms the significantly highest MBC build up was recorded under organic strawberry in Phulia and organic plot of Rice in Central Research farm of Gayeshpur.

Previously, FIesbach \& Mader (2000), in a long term experiment (18 years in organic farming) with permanent organic inputs, observed a higher microbial biomass. This confirms the current results. The soil microbial biomass $\mathrm{C}$ contents in the conventional farming were generally significantly lower than those in the soil from the organic farming, indicating that substantial disturbances through chemical fertilization, blanket pesticides, herbicides application may occur in the microbial biomass of the conventional agriculture. In microbial biomass nitrogen, organic systems favoured higher MBN build up where conventional system depressed it. Actually, 
more availability of organic $\mathrm{C}$ in the soils results in higher microbial populations and more $\mathrm{N}$ assimilation into the microbial cells. Upon microbial turnover, a significant proportion of this organic $\mathrm{N}$ released becomes part of the available $\mathrm{N}$ in the soils. Among the organic farms the significantly highest MBN build up was recorded under organic strawberry in Phulia and organic plot of Rice in Central Research farm of Gayeshpur.

Table.1 Microbial Biomass Carbon $(\mu \mathrm{g} / \mathrm{g})$ of different organic and conventionally managed plots during incubation period

\begin{tabular}{|l|c|l|c|c|c|c|c|}
\hline Site & Treatment & Status & 0 days & $\mathbf{2 1}$ days & $\mathbf{4 2}$ days & $\mathbf{6 3}$ days & $\mathbf{8 4}$ days \\
\hline Phulia & T1 & Organic strawberry & $209.98^{\mathrm{a}}$ & $190^{\mathrm{bc}}$ & $130.98^{\mathrm{c}}$ & $172.28^{\mathrm{b}}$ & $134.61^{\mathrm{b}}$ \\
\hline Phulia & T2 & Organic Rice & $140.43^{\mathrm{c}}$ & $197.96^{\mathrm{b}}$ & $150.85^{\mathrm{a}}$ & $186.14^{\mathrm{a}}$ & $124.81^{\mathrm{d}}$ \\
\hline Phulia & T3 & Conventional Rice & $134.93^{\mathrm{c}}$ & $159.33^{\mathrm{c}}$ & $130.67^{\mathrm{d}}$ & $124.81^{\mathrm{d}}$ & $129.57^{\mathrm{c}}$ \\
\hline Gayeshpur & T4 & Organic Rice & $150^{\mathrm{b}}$ & $203.72^{\mathrm{a}}$ & $148.93^{\mathrm{b}}$ & $165.27^{\mathrm{c}}$ & $178.73^{\mathrm{a}}$ \\
\hline Gayeshpur & T5 & Conventional Rice & $83.82^{\mathrm{d}}$ & $74.82^{\mathrm{d}}$ & $67.63^{\mathrm{e}}$ & $111.66^{\mathrm{e}}$ & $83.33^{\mathrm{e}}$ \\
\hline
\end{tabular}

Mean followed by common letter are not significantly different $(\mathrm{P}<0.05)$ by Duncan's Multiple Range Test and different letter indicates significant difference $(\mathrm{P}<0.05)$. $\left(\mathrm{T} 1=1 / 3^{\text {rd }}\right.$ of recommended $\mathrm{N}$ from FYM + Vermicompost + Neem cake, $\mathrm{T} 2=50 \% \mathrm{~N}$ from FYM + Azospirillum $+\mathrm{PSB}, \mathrm{T} 3=100 \% \mathrm{NPK}+\mathrm{ZnSO} 4, \mathrm{~T} 4=$ Sesbania green manure + Vermicompost + Mustard Oil Cake, T5 = 30: 60: $40 \mathrm{~N}: \mathrm{P}: \mathrm{K}$ )

Table.2 Microbial Biomass Nitrogen ( $\mu \mathrm{g} / \mathrm{g}$ ) of different organic and conventionally managed plots during incubation period

\begin{tabular}{|l|l|c|c|c|c|c|c|}
\hline Site & Status & Treatment & 0 days & $\mathbf{2 1}$ days & $\mathbf{4 2 ~ d a y s ~}^{\text {63 days }}$ & $\mathbf{8 4}$ days \\
\hline Phulia & Organic Strawberry & T1 & $23.33^{\mathrm{a}}$ & $20.74^{\mathrm{ab}}$ & $14.26^{\mathrm{c}}$ & $19.44^{\mathrm{a}}$ & $13.37^{\mathrm{b}}$ \\
\hline Phulia & Organic Rice & T2 & $16.85^{\mathrm{c}}$ & $21.04^{\mathrm{a}}$ & $16.85^{\mathrm{b}}$ & $18.15^{\mathrm{ab}}$ & $11.26^{\mathrm{d}}$ \\
\hline Phulia & Conventional Rice & T3 & $15.56^{\mathrm{d}}$ & $16.85^{\mathrm{b}}$ & $14.26^{\mathrm{c}}$ & $14.26^{\mathrm{c}}$ & $10.37^{\mathrm{e}}$ \\
\hline Gayeshpur & Organic Rice & T4 & $18.15^{\mathrm{b}}$ & $20.74^{\mathrm{ab}}$ & $18.15^{\mathrm{a}}$ & $18.15^{\mathrm{ab}}$ & $19.44^{\mathrm{a}}$ \\
\hline Gayeshpur & Conventional Rice & T5 & $11.67^{\mathrm{e}}$ & $9.85^{\mathrm{c}}$ & $10.37^{\mathrm{d}}$ & $15.55^{\mathrm{b}}$ & $12.96^{\mathrm{c}}$ \\
\hline
\end{tabular}

Mean followed by common letter are not significantly different $(\mathrm{P}<0.05)$ by Duncan's Multiple Range Test and different letter indicates significant difference $(\mathrm{P}<0.05)$

Microbial community is an important component of soil which can regulates various soil related functions like soil respiration, nutrient transformation, maintaining soil reaction. As organic carbon is the most important factor of microbial biomass content so organic farming is one of the important cultivation practices which should be followed.

\section{References}

Alexander, M. 1977. Introduction to Soil Microbiology. New York: Willey and Sons.
Araujo, \& Melo. 2011. Soil microbial biomass carbon and nitrogen as affected by cropping systems. Biology and Fertility Soils 31: 200-210.

Flesbach, \& Mader. 2000. Nutrient considerations for diversified cropping systems in the Northern Great Plains. Agronomy Journal 94: 186-198.

Joergensen, R.G. 1995. Microbial biomass. In: methods in applied microbiology and biochemistry (Alef, K. and Nannipeiri, P., eds.). Academic Press, pp.382-386. 


\section{How to cite this article:}

Soumyabrata Chakraborty and Niharendu Saha. 2020. Assessment of Microbial Biomass Carbon and Microbial Biomass Nitrogen of Incubated Organic and Conventional Treated Soil in West Bengal. Int.J.Curr.Microbiol.App.Sci. 9(05): 1197-1200.

doi: https://doi.org/10.20546/ijcmas.2020.905.133 